\title{
Mechanism for Interaction between the Participants of Science and Education Complex
}

\author{
Olga Nikolaevna Vladimirova, Aleksey Olegovich Slavikovskiy \\ School of Economics and Commerce, Siberian Federal University \\ 2 Lidy Prushinskoy Street, Krasnoyarsk City 660075, Russia \\ olga.ovladimirova24@yandex.ru, slavikovskiy86@mail.ru
}

\begin{abstract}
In modern conditions, the special focus is on the selection and justification of the optimal organizational option within the framework of improving the efficiency in the interaction between the participants of an innovative economy. The authors propose to use the form of a Science and Education Complex (SEC).

The objective of this paper is to develop a mechanism for interaction of a Scientific and Education Complex in the field of education, research, and innovation. Based on the analysis of the foreign practice in cooperation of science, education, and business, there is argued the possibility of implementing a complex integrated model in the Russian environment to account for the development peculiarities related to the regions of SEC formation.

The study completed on the current trends in the development of science and new trends in education reforms, the identification of a SEC specific features and differences of the latter from the science and education clusters allowed to develop the option of a mechanism for interaction between the participants of a Science and Educational Complex. One of the largest constituent entities of the Russian Federation, the Krasnoyarsk Territory, is used as an example to illustrate the entities, permissible regulatory instruments, and institutions as well as to formulate the principles for interaction. The study and compilation of international and Russian statistical databases characterizing the performance indicators of scientific, innovation, education and business activities resulted in proposing the system of indicators to assess the effectiveness in the SEC functioning in terms of key groups of participants.

Keywords: science and education complex, interaction mechanism, science and education integration, innovation activity
\end{abstract}

\section{Introduction}

The post-industrial way of social reproduction and development applied to the concept of a knowledge society determined to change the vector of the world economy towards innovation. The innovatory international experience shows that the limit value of the innovation activity can be achieved at the point of interests intersection of the four main actors in the economy: state, business structures, scientific and educational professional institutions. Particularly, the source of innovation processes are higher educational institutions, while the state and business structures serve as customers, consumers, and co-investors for the scientific research and innovation solutions. Therefore, the growing interest from the scientific and educational community, the state, and business, to the issues of selection and justification of an optimal organ- 
izational interaction is explained by the relevance of the problems under analysis to Russia.

With the view to the above, the objective of this study is to develop a mechanism for interaction between the participants of SEC in science, education, and innovation (based on the example of the Krasnoyarsk Territory).

\section{Review of Literature}

Currently, a considerably large number of foreign research works are devoted to problems of integration processes in science, education, state, and business, as well as commercialization of fundamental knowledge and challenges related to the implementation of scientific research into the production. These problems are mainly referred to in the studies completed in the USA (T. Bailey, D. Baker, D. Frank, P. Gumport, L. Leslie, H. Nowotny, P. Scott, C. Tamasy, B. Wynne), Great Britain (M. Ash, T. Brunch, J.L. Davies, D.A. Kirby), Canada (B. Austin, A. Chan, N. Tudiver), Japan (K. Kitamura, S. Moriya, K. Okamoto), and the Netherlands (I. Bleiklie, S. Craciunoiu, M. Henkel) [13, 15, 21].

The problems of choosing the optimal form for interaction between the participants of the innovation economy at the regional level are specifically observed in the works of Russian scientists: E.E. Agafonova, S.G. Boev, Yu.L. Esina, L.P. Kleeva, D.Yu. Lapygina, S.S. Malina, N.M. Stepanenkova [2, 5, 7, 10, 12].

Modern trends in cluster cooperation of science, education, and business are considered in the works of both foreign (M. Delgado, G. Lindqvist, A. Nuseibah, M. Porter, S. Stern K. Wennberg, C. Wolff) and Russian (E.V. Barasheva, N.N. Davydova, E.M. Dorozhkina, E.V. Gorbachevskaya, I.I. Zedgenizova, N.V. Polyanskova) scientists $[1,3,22,23,25,26]$.

\section{Methodology}

The reference to the foreign experience enables selecting a number of approaches to form the interaction of science and education within a unified complex $[15,16]$. The first is the American model, which is based on the concept developed by the research universities (Australia, the UK, Canada, the USA). A research university acts as a core in the interaction process and undertakes the responsibility to develop, implement, and promote the innovations as well as to create links with the industrial sector of economy [6]. Therefore, it becomes a powerful scientific research, educational and industrial complex conducting close cooperation with the state and business.

The second approach is based on the Japanese model, where the key role is played by the state (Hong Kong, People's Republic of China, South Korea, Japan). Following the analysis of the practical experience and success achieved by the USA, the Government of Japan preferred to integrate science, education, and business in the form of a "Technopolis" representing the major scientific centers - "technology cities" with state financing and management. In technopolises, the scientific core is the universities of Hokkaido, Akita, Hiroshima, Tsukuba, Kagoshima. In addition, the financing of technopolises themselves, unlike the US research universities, is carried out through the means of the region and big private capital [13].

The third mixed type of integration of science and education within a unified complex, where the key role is given to technology park structures, is widespread in the European countries (Belgium, Germany, France, Sweden) [13, 16]. These can be in 
the form of technology or research parks, sometimes growing up to agglomerations similar to technopolises but distinguished by the active participation of the science parks administration rather than the state as it is in Japan. Universities (except for the UK), as well as in the Japanese model, has an educational function without focusing on industrial and technological developments and their commercialization, but actively take steps to attract appropriate structures to cooperate in this respect.

Foreign experience confirms that the use of a specific model to form the integrative SEC plays an important role in the development and increase in the state competitiveness under conditions of the country's economy switch to the innovation way of development.

According to the authors, the SEC is one of the forms to integrate into a unity all the chains and fields of science and education to implement education, research, and innovation activity. The necessity and importance of its formation and functioning are determined by its role in providing national and economic security of the state and preparing highly competitive experts.

Specific characteristics of SEC in Russia manifest themselves as follows [4]:

1. The core of the science institutional structure are the legally independent research organizations;

2. The scope of research and development works are mostly concentrated in the system of the Academy of Sciences and industry - related Research Institutes and Design Bureaus;

3. Given the drastic reduction of the structures for the transfer of scientific achievements into the innovation sphere, there is detected a growing number of Research Institutes either through divestiture of operating organizations or by creating new ones, rather than on the basis of strengthening of the research capacity of higher education institutions and enterprises;

4. The previously formed SEC allowed to preserve the integrity of the system of science and education with the simultaneous increase in the archaism of their institutional structure.

\section{Discussion}

Analysis of existing forms of integration proves ascendancy of clusters in the modern economy, which are one of the most effective forms of cooperation providing the necessary competitive advantages. In addition, the common for the SEC and the scientific educational cluster is science and science environment that they are a stable system for the spread of new knowledge, products and technologies, in other words, provide technology network [9].

However, according to the authors, the difference between the scientific educational cluster and the SEC is based on:

1. Certain horizontal, vertical and mixed relations, through which the participants must be connected;

2. Geographical proximity, since the co-location favorably affects the formation and increase of advantages;

3. Maximization of the market mechanism, i.e. a cluster can be effective only when it is created at the initiative of all interested parties on the basis of cocompetition; 
4. Functions for creating main aspects of regional development, which through own development create conditions for the development of the cluster itself.

However, as M. Porter, the founder of the cluster theory, noted, the typical for Russia main problems as insufficiently developed infrastructure, lack of competition, state intervention into the private economy and a weak judicial system form serious barriers to the development of this form of integration between science, education, and business [2]. Despite this, the desired synergy effect from accumulating in one complex research, education and innovation leads to the fact that at a certain stage of development the formed SEC begins to show characteristics of a clustered structure.

\section{Practical Relevance}

The study completed on the current trends in the development of science and new trends in education reforms, the identification of a SEC specific features and differences of the latter from the science and education clusters allowed to develop the option of a mechanism for interaction between the participants of a Science and Educational Complex in the Krasnoyarsk Territory (Fig. 1). The region is a typical representative of the mixed model of integration of science and education with a welldeveloped science and education sphere, a large corporate sector of research and development.

The proposed mechanism of cooperation between the SEC participants is based on the following principles:

1. Voluntary integration, i.e. harmonization of interests of the participants for their active motivation on productive activities in the new conditions of the integrated complex;

2. Optimal and effective use of the united personnel, material, and financial resources;

3. Mandatory state participation;

4. Establishing conditions for science, education, and innovation within a complex;

5. Complexity based on the structural identification of the participants;

6. Monitoring of the effectiveness of the complex functioning.

Scientific and educational sphere of the Krasnoyarsk Territory is represented by Krasnoyarsk Scientific Center of Siberian Branch of the Russian Academy of Sciences, industry-related research institutes, 10 Federal State higher education institutions and a network of their branches. The main strategic advantage and the largest center of education in the Territory is the Siberian Federal University. Krasnoyarsk scientific institutions, engineering school and higher education system having been integrated into the Federal University for 5-10 years, with some support from the state and regional authorities, as well as interest in the participation of business, must take a leading position in the world for training highly-qualified experts and implementation of priority scientific research and technological developments. A similar development way was taken and tested by specific universities, such as the Technion in Israel, Manchester in the UK, universities in the Canadian province of Alberta [5].

The Ministry of Education of the Krasnoyarsk Territory (science) and the Ministry of Economic Development and Investment Policies of the Krasnoyarsk Territory (innovations) resolves issues on developing the science, education and innovation potential of the Territory. 


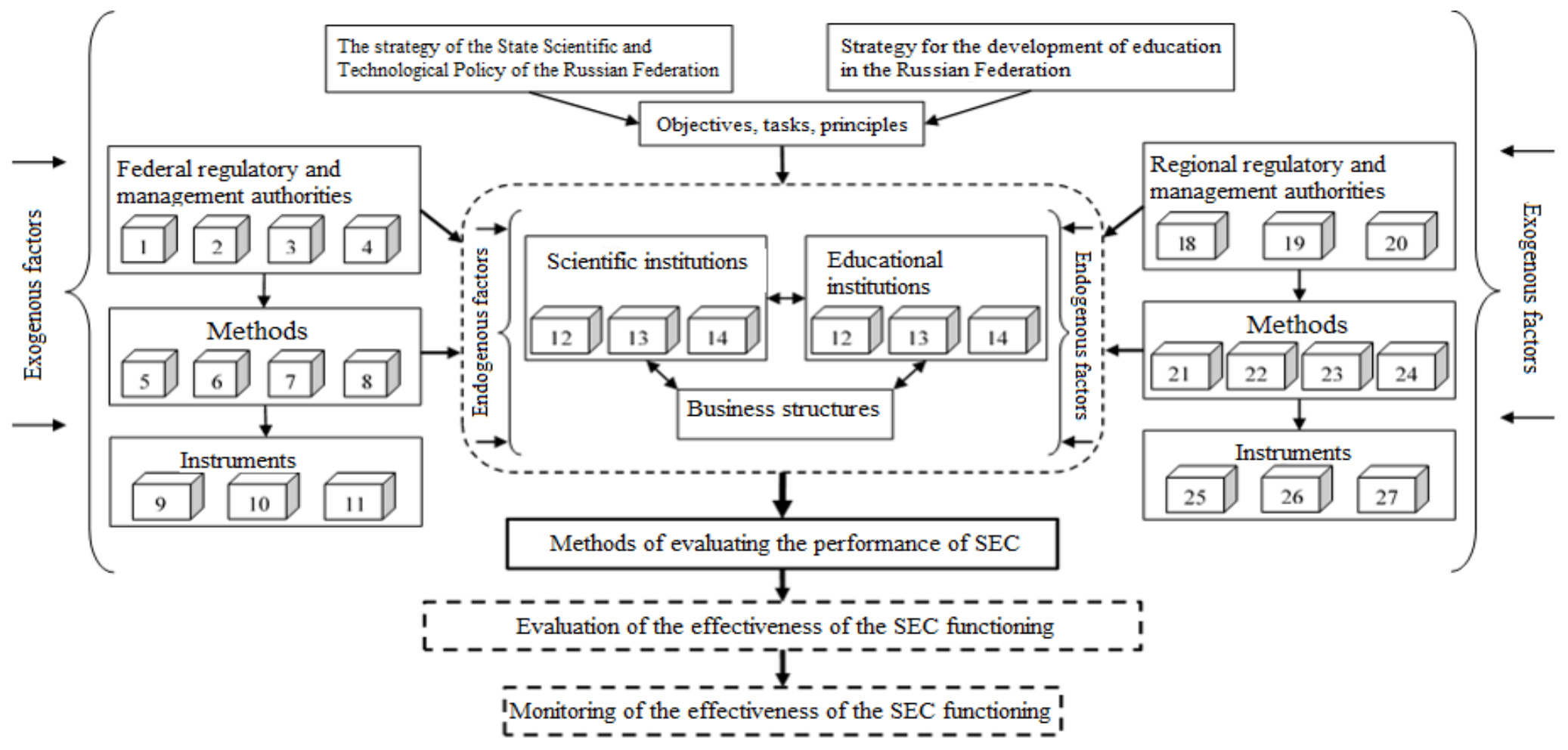

Fig. 1. Mechanism of interaction of the SEC participants in the Krasnoyarsk Territory 
Financial infrastructure of supporting science and innovation is represented by the established Territorial Autonomous Institution "Krasnoyarsk Territory Fund for the Support of Scientific and Technical Activity", while the object of physical innovation infrastructure is the Krasnoyarsk State Autonomous Institution "Krasnoyarsk Regional Innovation and Technology Business-Incubator".

In April 2016, the Government of the Krasnoyarsk Territory adopted the Decree on approving the subprogramme "Development and Enhancing the Global Competitiveness of Science and Education Complex and Innovative System of the Krasnoyarsk Territory", the most important priority of which is the construction of industrial science park on the territory of the Zheleznogorsk Town in the interests of social and economic development and technological modernization of industries in the territorial economy.

According to the composite index of innovative activity of regions in 2015, the Krasnoyarsk Territory, as a representative of the Siberian Federal District (SFD), entered the top ten most innovatively active regions of Russia, after the Tomsk Region only [17]. According to the education level of the population, the region takes the 56th place among the constituent entities of Russia, according to the number of highly qualified personnel employed in science it is in the 66th place, according to the value proportion of contributions to the civic science, the 19th place [17, 18]. Currently, the innovation sector does not play a significant role in the regional economy: enterprises of the Territory mainly produce traditional products, and the share of hightech and knowledge-based industries in GRP in 2016 amounts to 14.4\%, which is below average in the Siberian Federal District and innovation-active regions of Russia [18].

The mechanism for interaction of the SEC participants must have certain advantages that are provided by the education both to participants and the constituent entity of the Federation within which it is planned to be established. The study of international and Russian statistical databases characterizing the performance indicators of scientific, innovation, education and business activities resulted in the authors' proposing the system of indicators to assess the effectiveness in the SEC functioning in terms of key groups of participants (Fig. 2, 3).

Thus, the possibility of evaluating the performance of the SEC functioning allows to make an informed decision on the necessity of its development within the region.

\section{Conclusions}

In the conditions of the innovation economy development, an important task in the field of science and education is the search for the optimal form of their organization to ensure their integration, both between themselves and with the state and business structures. According to the authors, the integrated approach acts as an effective way of forming the innovation economy since SEC is an effective instrument to accommodate the interests of the scientific and educational environment and business. The SEC feature is manifested in its function of forming the main aspects of regional development, which developing themselves determine the development of the complex.

Thus, the integrated approach is an effective method of transferring the country's economy to the innovation way of development. The proposed mechanism of cooperation between the SEC participants in the Krasnoyarsk Territory contributes to the 
increased access to technology and innovation, improved quality of personnel training, increased commercialization of scientific developments, i.e. forming in the Territory the innovation economy, as well as the organization of a large scientific and educational center in the entire state.

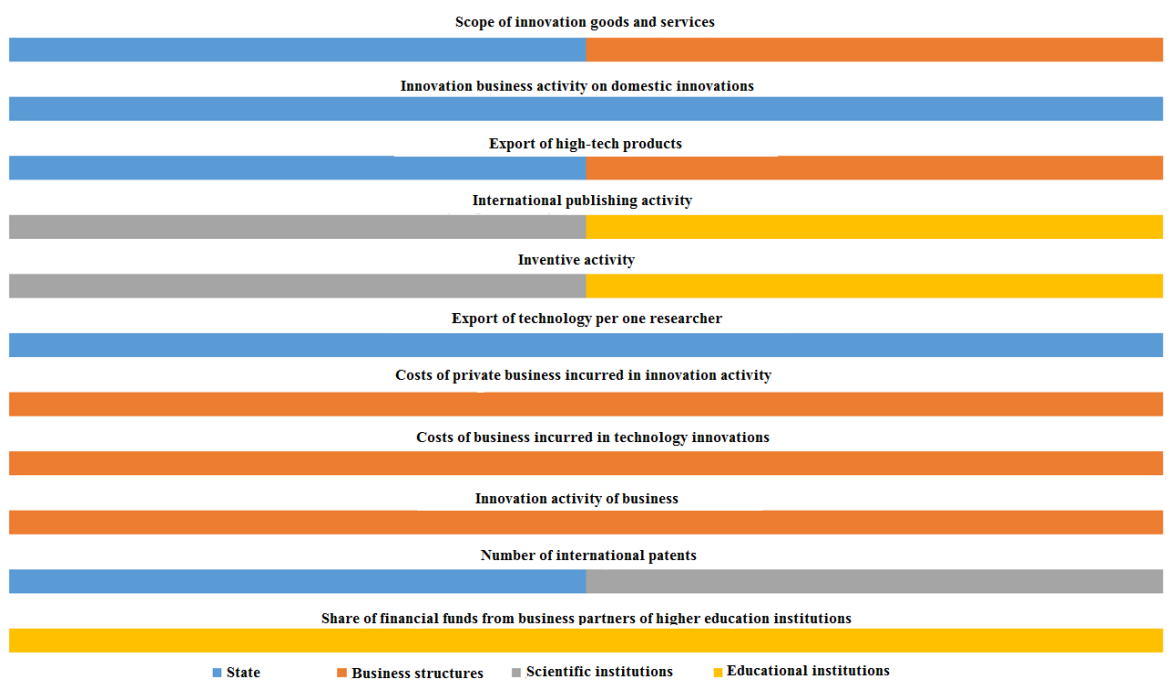

Fig. 2. Indicators for assessing the economic efficiency of the SEC functioning

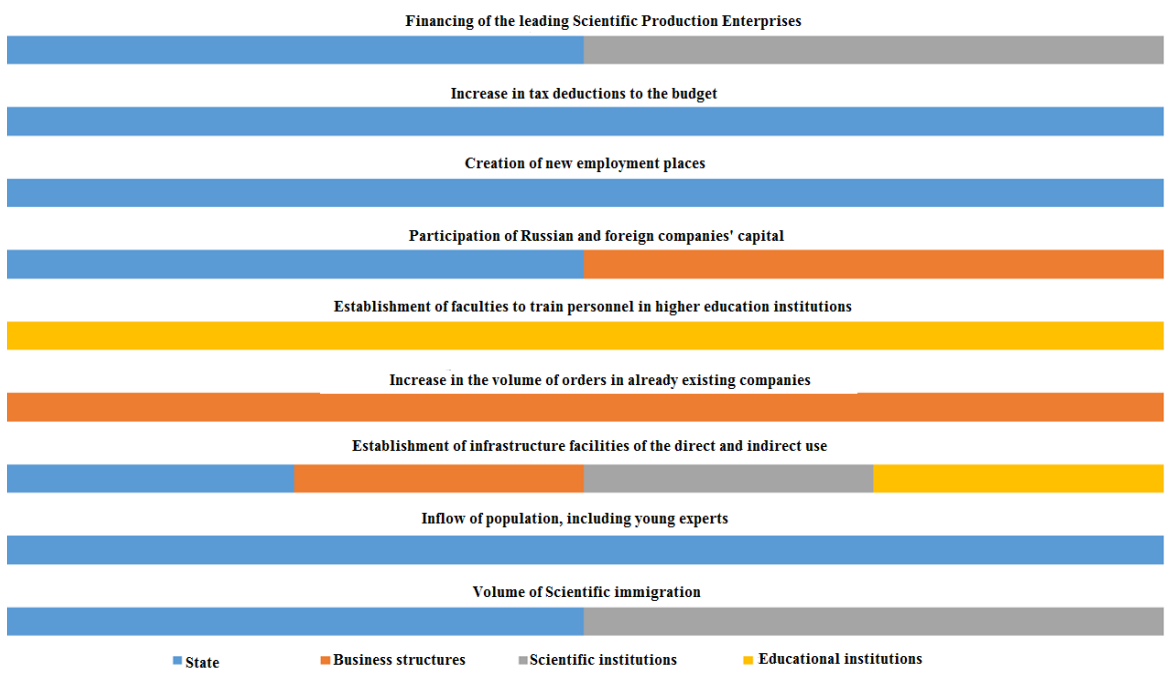

Fig. 3. Indicators for assessing the social efficiency of the SEC functioning

\section{References}

1. E.V. Barasheva, I.I. Zedgenizova. Innovacionnye klastery kak osnova integratsii nauki i obrazovaniya [Innovation Clusters as the Basis of Science and Education Inte- 
gration] // Upravlenie ehkonomicheskimi sistemami [Economic Systems Management]. - 2017. No. 11 (105) [Electronic resource]. URL: http://uecs.ru/index.php?option= com_flexicontent\&view=items\&id=4622 (Reference date: November 15, 2017)

2. S.G. Boev. Integratsiya nauki, obrazovaniya i proizvodstva, kak osnova innovatsionnogo razvitiya ekonomiki [Integration of Science, Education and Production as the Basis for Innovation Development of Economy] // Ekonomist [Economist], 2015. No. 7, P. 58-72.

3. E.V. Gorbachevskaya. Kompleksnaya kharakteristika ekonomicheskikh klasterov [Complex Description of Economic Clusters] // Nauka i praktika [Science and Practice]. 2009. No. 2 (2). P. 142-150.

4. L.M. Gokhberg, G.V. Kitova, T.A. Kuznetsova. Strategiya integratsionnykh protsessov v sfere nauki i obrazovaniya [The Strategy of Integration Processes in the Field of Science and Education] // Ekonomika obrazovaniya [Education Economy]. 2009. No. 1 (1). P. 67-79.

5. Yu.L. Esina, N.M. Stepanenkova, E.E. Agafonova. Formy i mekhanizmy integratsii nauki, obrazovaniya i biznes-soobshchestva $\mathrm{v}$ usloviyakh innovatsionnogo obnovleniya regional'noy ekonomiki [Forms and Mechanisms of Integration of Science and Education and the Business Community in Terms of Innovation Update of the Regional Economy] // Kreativnaya ekonomika [Creative Economy]. 2015. No. 9 (12). P. 1491-1508.

6. I.I. Ignatov. Universitetskij sektor SShA i rossiyskie reformy v sfere nauki i vysshego obrazovaniya [The USA University Sector and Russian Reforms in theSphere of Science and Higher Education] // Federal Internet Edition Kapital strany [Capital of the Country]. - 2012. [Electronic resource]. URL: http://kapitalrus.ru/articles/article/universitetskij_sektor ssha i rossijskie reformy v oblasti nau ki_i_vysshego/ (Feference date: October 21, 2017)

7. L.P. Kleeva. Razvitie nauchno-obrazovatel'nykh kompleksov regionov Rossii [Development of Scientific and Educational Complexes Regions of Russia] // Energiya: ekonomika, tekhnika, ekologiya [Energy: Economy, Technology, Ecology].2015. No. 10. P. 2-8.

8. Kontseptsiya dolgosrochnogo sotsial'no-ekonomicheskogo razvitiya Rossijskoj Federatsii na period do 2020 goda [The Concept of Long-term Social and Economic Development of the Russian Federation for the Period until 2020] [Electronic resource]. URL: http://docs.cntd.ru/document/902130343 (Reference date: May 6, 2018).

9. N.S. Kocherga. Sravnitel'nyj analiz razlichnykh vidov integratsii biznes soobshchestva, nauki i obrazovaniya: aktual'nye aspekty stanovleniya [Comparative Analysis of Different Types of Integration of Business Community, Science, and Education: Current Aspects of Formation] // Statistika i ekonomika [Statistics and Economics]. 2014. No. 6 (2). P. 299-303.

10. D.Yu. Lapygin. Integratsiya obrazovaniya i nauki kak faktor strategicheskogo razvitiya regiona [Integration of Education and Science as a Factor in the Strategic Development of the Region] // Regionologiya [Regional Studies]. 2015. No. 1. P. 107-113. 
11. E.A. Maksimova. Klassifikatsiya obrazovatel'nykh ob"edinenij [Classification of Educational Associations] // Izvestiya Saratovskogo universiteta [Publications of Saratov University]. New series: Philosophy. Psychology. Pedagogics. 2016. No. 2. P. 220-225.

12. S.S. Malina. Rol' subektov nauchno-obrazovatel'nogo kompleksa v razvitii innovatsionnoj ekonomiki regiona [Role of Subjects of the Science and Education Complex in the Development of the Innovation Economy of the Region] // Innovatsii $\mathrm{i}$ investitsii [Innovation and Investment]. 2015. No. 1. P. 91-95.

13. V. MinMin, G.V. Petruk. Nauka, obrazovanie i biznes: zarubezhnyj i otechestvennyj opyt integratsionnogo vzaimodejstviya [Science, Education, and Business: International and Ddomestic Eexperience of the Integration Interaction] //Azimut nauchnykh issledovanij: ekonomika i upravlenie [Azimuth Research: Economics and Management]. 2017. No. 2 (19). P. 216-219.

14. V.V. Narbut. Nauchnyj potentsial Sibirskogo federal'nogo okruga: sostoyanie i perspektivy razvitiya [Scientific Potential of the Siberian Federal District: State and Prospects of Development] // Nauka o cheloveke: gumanitarnye issledovaniya [Science of a Human Being: Humanitarian Research]. 2015. No. 4 (22). P. 206-212.

15. E.V. Neborskij. Zarubezhnyj opyt integratsii obrazovaniya, nauki i biznesa [Foreign Experience of Integration of Education, Science, and Business] // Vestnik Baltijskogo Federal'nogo universiteta im. I. Kanta. [Bulletin of the Baltic Federal University named after I. Kant.]. 2012. No. 11. P. 33-40.

16. A.R. Nurutdinova, E.V. Dmitrieva. Vzaimosvyaz' obrazovaniya, nauki i proizvodstva: forma realizatsii i klassifikatsiya (otechestvennyj i zarubezhnyj opyt) [Interrelation of Education, Science, and Production: the Form of the Realization and Classification (Domestic and Foreign Experience)] // Aktual'nye problemy gumanitarnykh i estestvennykh nauk [Topical Problems of the Humanities and Natural Sciences]. 2015. No. 9 (2). P. 130-133.

17. Regiony Rossii. Sotsial'no-ekonomicheskie pokazateli [Regions of Russia. Social and Economic Indicators]. 2017: Stat.sb. / Rosstat.[Statistical Collection, Russian Statistics]: Moscow, 2017, 1402 p.

18. Rossijskij statisticheskij ezhegodnik [Russian Statistics Annual Editions], 2017: Stat.sb./Rosstat.[Statistical Collection, Russian Statistics]: Moscow, 2017, 686 p.

19. A.G. Sanina. Usloviya integratsii nauki, obrazovaniya i biznesa v sovremennoj Rossii [Conditions of Integration of Science, Education, and Business in Modern Russia] // Sotsiologicheskie issledovaniya [Social Research]. 2010. No. 7. P. 122129.

20. Strategiya nauchno-tekhnologicheskogo razvitiya Rossijskoj Federatsii [Scientific and Technological Development Strategy of the Russian Federation] [Electronic resource]. URL: http://docs.cntd.ru/document/420384257 (Reference date: May 6, 2018).

21. S. Bodrunov. Integration of Manufacturing, Science, and Education as a Basis for the Re-industrialization of Russia // World Economy and International Relations. 2015. 10 (59). P. 94-104. 
22. Davydova N.N., Dorozhkin E.M., Polyanskova N.V., Nuykina E.Y. Formation of a cluster integration system of educational institutions within the region // International Journal of Environmental and Science Education. 2016. 16. P. 9206-9221.

23. Delgado M., Porter M., Stern S. Clusters, convergence, and economic performance // Research Policy. 2014. 10 (43). P. 1785-1799.

24. Tyaglov S., Garibova E., Cheremina V. Cooperation of government agencies, enterprises and educational structures: Regional features and prospects for integration // Actual Problems of Economics. 2016. 4 (178). P. 221-231.

25. Wennberg K., Lindqvist G. The effect of clusters on the survival and performance of new firms // Small Business Economics. 2010. 3 (34). P. 221-241.

26. Wolff C., Nuseibah A. A projectized path towards an effective industryuniversity-cluster: Ruhrvalley // Proceedings of the 12th International Scientific and Technical Conference on Computer Sciences and Information Technologies (CSIT). 2017. P. 123-131. 